\title{
KUASA TUHAN NYATA SEMPURNA DALAM KELEMAHAN MANUSIA DI TINJAU DARI II KORINTUS 12:9
}

\author{
Oleh: Eka Preskila
}

\author{
estershintia2809@gmail.com
}

\begin{abstract}
In II Corinthians, Paul wrote if he has a thorn in the flesh, and he asked the Lord about that, that it depart from him. As we know Paul was a great missionary, how his obedience and braveness for Christ, he is one of the famous Prophetes. But God's said to Paul if His Grace is enough for him, and His power's made perfect in weaknes. So, what the meaning of the thorn? What God's answered to Paul about that? And actually, what Paul felt after God's answered?
\end{abstract}

Keywords: Paul, Thorn in the flesh, weaknes, Grace, Power made perfect in weaknes

\begin{abstract}
Abstrak
Dalam surat II Korintus, Paulus menuliskan bahwa dalam dirinya terdapat duri dalam daging, sehingga ia meminta kepada Tuhan untuk melepaskan duri iru dari dalam dirinya. Seperti yang telah diketahui, bahwa Paulus adalah seorang misionaris yang besar, yangbegitu taat dan berani demi Injil Kristus, dia adalah salah satu rasul yang terkenal. Menaggapi hal itu, Tuhan berkata kepada Paulus bahwa Telah cukup anugerah-Nya bagi Paulus dan kekuatan-Nya nyata dan sempurna di dalam kelamahan. Jadi, apa sebenarnya yang dimaksud dengan duri dalam daging? Apa jawaban Tuhan mengenai hal itu? Dan bagaimana reaksi Paulus setelah mendengar jawaban dari Tuhan?
\end{abstract}

Kata Kunci: Paulus, duri dalam daging, kelemahan, Anugerah, kekuatan yang sempurna dalam kelemahan. 


\section{PENDAHULUAN}

\section{Latar Belakang}

II Korintus merupakan surat yang ditulis oleh Paulus untuk jemaat di Korintus. Korintus merupakan sebuah ibukota propinsi, yakni propinsi Akhaya. Sebagai ibukota Propinsi tentunya Korintus adalah kota yang maju, makmur, baik secara materi maupun intelektual, sayangnya penduduk kota Korintus juga terkenal dengan kebejatan moral. ${ }^{1}$

Paulus menulis surat ini sekitar tahun 55/56 M, di Makedonia. Alasan Paulus menulis surat ini dikarenakan adanya guru-guru palsu yang menentang kerasulan Paulus, bahkan ada minoritas dari jemaat yang ikut melawan. ${ }^{2}$ Ada yang berkata bahwa Paulus tidaklah sebaik dan seefektif seperti gambaran yang terlihat dari surat-suratnya, sehingga Paulus pun mengakui kekurangannya bahkan ia menceritakan pengalaman dalam penglihatan dan penyataan dari Tuhan tentang surga. ${ }^{3}$

Dalam II Korintus ini para musuh Paulus teridentifikasi secara jelas, mereka berlatar belakang apologet Yahudi hellenis atau gerakan hikmat Yahudi atau dikenal pula sebagai ajaran Kristologi Theos Aner artinya ajaran yang menekankan kehebatan seorang manusia Ilahi. Melalui surat ini Paulus memperkenalkan mereka kepada jemaat di Korintus bahwa mereka adalah rasul-rasul palsu atau pekerja-pekerja curang. ${ }^{4}$

Maksud penulisan surat ini terkait erat dengan pertikaian yang pernah terjadi sebelumnya. Berdasarkan hal itu ia ingin membenarkan dirinya dari tuduhan yang sudah dikenakan pada dirinya, sekaligus menjelaskan bahwa ia adalah rasul yang sebenarnya dan bukan rasul palsu

\footnotetext{
1 _ Alkitab Penuntun Hidup Berkelimpahan, (Malang: Gandum Mas), 1994, hal. 1877

2 Ibid, hal. 1916.

3 _ Tafsiran Alkitab Wycliffe, (Malang: Gandum Mas), 2013, hal. 904.

4 Yupiter Hulu, Diktat Pengantar Perjanjian Baru, (Yogyakarta: Sekolah Tinggi Theologia Nazarene Indonesia), 2013.
} 
seperti yang mereka tuduhkan, dengan menceritakan pengalamannya tentang penglihatan dan penyataan Tuhan.

Awalnya Paulus enggan menceritakan pengalamannya tentang penyataan Tuhan itu, namun ia terpaksa melakukannya sebagai pembelaaan atas kerasulannya. Bahkan ia menulis kekurangannya sebagai suatu “duri” didalam daging. Sehingga dalam II Korintus 12:8 itu Paulus bahkan berseru kepada Tuhan sampai tiga kali. Lalu bagaimana jawaban Tuhan atas seruan Paulus, hamba yang selama ini berjuang, rela disiksa dan kesetiaanya tidak diragukan lagi demi Injil? Apa sebenarnya "duri” dalam daging yang ada pada Paulus? Apakah kelemahan yang ada dalam diri Paulus? Adakah “duri” itu merupakan dampak dari siksaan yang ia alami?

Berangkat dari pertanyaan-pertanyaan tersebut, penulis tertarik untuk menggali lebih dalam mengenai Kuasa Tuhan dalam kelemahan Paulus, dengan judul "Kuasa Tuhan Nyata Sempurna Dalam Kelemahan Manusia Ditinjau Dari II Korintus 12:9

\section{PEMBAHASAN}

Dalam II Korintus 12:9 ada tertulis "Tetapi jawab Tuhan kepadaku: "Cukuplah kasih karunia-Ku bagimu, sebab justru dalam kelemahanlah kuasa-Ku menjadi sempurna”. Sebab itu terlebih suka aku bermegah dalam kelemahanku, supaya kuasa Kristus turun menaungi aku.",5

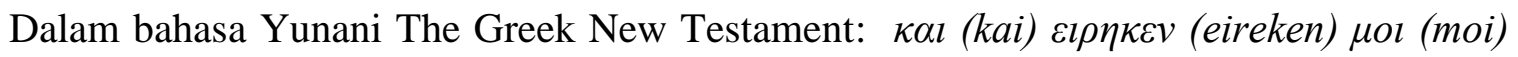

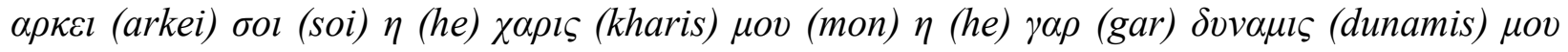
(mon) $\varepsilon v$ (en) $\alpha \sigma \theta \varepsilon v \varepsilon \imath \alpha$ (asteneia) $\tau \varepsilon \lambda \varepsilon \imath \tau \alpha \imath$ (teletai) $\eta \delta \imath \sigma \tau \alpha$ (hedista) ovv (un) $\mu \alpha \lambda \lambda o v$ (mallon)

\footnotetext{
${ }^{5}$ Aplikasi Android TB, Versi 4.5.5, SABDA dan Tim Alkitab Android 2019.
} 


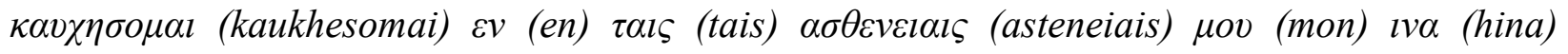

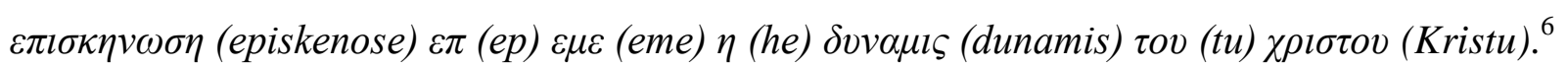

Melihat ayat sebelumnya (7-8), secara kontekstual ayat ini (ayat 9) merupakan jawaban Tuhan atas permohonan (doa) Paulus. Dimana sebelumnya Paulus berkata bahwa ia diberi suatu "duri" didalam daging, sehingga ia berseru kepada Tuhan bahkan sampai tiga kali agar Tuhan melepaskan ia dari "duri" dalam daging tersebut. Sebelum masuk kedalam pembahasan yang lebih dalam, yang dimaksud dengan duri dalam daging ini harus diperjelas terlebih dahulu.

Dalam versi New International Version (NIV), menggunakan kata "To keep me from becoming conceited because of these surpassingly great great revelation, there was given me a thorn in my flesh, a messenger of Satan, to torment me.",

Sedangkan dalam Alkitab Bahasa Indoneisa Masa Kini (BIMK) menggunakan kata "semacam penyakit pada tubuh saya yang merupakan alat iblis. Penyakit itu diberikan untuk memukul saya supaya saya tidak menjadi sombong."

Alkitab Versi Mudah Dibaca (VMD), menggunakan kata "hal yang menyakitkan diberikan kepadaku. Malaikat setan diutus untuk memukul dan menahan aku supaya jangan terlalu bangga." 9

Yang dimaksud "duri” dalam daging itu dalam bahasa Yunani adalah $\sigma \kappa o \lambda o \psi$ (skolops), merupakan kata benda, maskulin yang artinya a stake or thorn, fig, a sharp affliction, yang dalam bahasa Indonesia artinya duri atau pasak, keremehan, penderitaan yang tajam.

\footnotetext{
${ }^{6}$ Hasan Sutanto, Perjanjian Baru I nterlinear Yunani-Indonesia dan Konkordansi Perjanjian Baru (PBIK) Jilid I, (Jakarta: Lembaga Alkitab Indonesia), 2014, hal. 995.

${ }^{7}$ Hasan Sutanto, Perjanjian Baru I nterlinear Yunani-Indonesia dan Konkordansi Perjanjian Baru (PBIK) Jilid I, (Jakarta: Lembaga Alkitab Indonesia), 2014, hal. 995.

${ }^{8}$ Aplikasi Android BIMK, Versi 4.5.5, SABDA dan Tim Alkitab Android 2019.

9 Aplikasi Android VMD, Versi 4.5.5, SABDA dan Tim Alkitab Android 2019.
} 
Menurut Kamus Besar Bahasa Indonesia (KBBI) duri adalah bagian tumbuhan yang runcing dan tajam seperti pada bunga mawar; bulu binatang yang kaku dan tajam seperti pada landak; tulang ikan yang runcing-runcing dan tajam. ${ }^{10}$ Sedangkan pasak artinya paku yang dibuat dari kayu, bambu, dan sebagainya. ${ }^{11}$

Sedangkan dalam buku Bahasa Lambang Alkitab, menyebutkan bahwa duri merupakan suatu lambang yang menggambarkan pengalaman-pengalaman pedih dan tidak menyenangkan, yang diijinkan Allah sebagai sarana pengajaran bagi umat-Nya. ${ }^{12}$

Duri dan pasak dalam hal ini tidak digunakan secara literal, melainkan kiasan. Paulus memakai istilah itu untuk mengkiaskan atau menggambarkan rasa sakit yang ia rasakan. Dari penjelasan yang terdapat dalam alkitab berbagai versi yang di maksud Paulus dengan "duri” adalah suatu penyakit tubuh yang menyakitkan, yang berasal dari utusan iblis supaya dirinya (Paulus) tidak menjadi sombong. Kata “duri” dalam daging artinya bisa saja mengenai kesakitan, kesukaran, penderitaan, penghinaan atau kelemahan secara fisik. ${ }^{13}$

Banyak tafsiran mengenai makna sesungguhnya dari "duri" dalam daging yang dialami Paulus, apakah hal itu merupakan suatu penyakit, kelemahan fisik atau cacat, atau bahkan suatu keadaan yang sangat sulit yang Paulus jumpai selama perjalanan misinya. Namun menurut William Barclay dalam bukunya Duta Bagi Kristus: Latar Belakang Peta Perjalanan Paulus mengemukakan beberapa tafsiran mengenai arti "duri” yang dimaksud Paulus: ${ }^{14}$

\footnotetext{
${ }^{10}$ Departemen Pendidikan Dan Kebudayaan, Kamus Besar Bahasa Indonesia, (Jakarta: Balai Pustaka), 1988, hal. 216.

${ }^{11}$ Ibid, hal. 650 .

12 W. Stuart Owen, P.A Grist, R.Dowling, Bahasa Lambang Alkitab (Jakarta: Yayasan Komunikasi Bina Kasih), 2003, hal. 58.

13 , Alkitab Penuntun Hidup Berkelimpahan, (Malang: Gandum Mas), 1994, hal. 1936.

14 William Barclay, Duta Bagi Kristus: Latar Belakang Peta Perjalanan Paulus, (Jakarta: BPK Gunung Mulia), 1985, hal. 4.
} 
Pertama, merupakan suatu penyakit, dalam konteks sebelumnya Paulus berkata dalam Galatia 4:14, 15; Paulus mengatakan kepada jemaat di Galatia bahwa ia memiliki suatu penyakit, dan ia merasa bahagia karena meskipun demikian jemaat Galatia tidak menganggap itu sebagai sesuatu yang hina dan yang menjijikkan.

Perlu diketahui secara historikal, orang-orang pada jaman itu berkeyakinan bahwa penyakit ditimbulkan karena adanya roh jahat yang hinggap pada diri seorang yang sakit tersebut, sebab itu ada yang menduga bahwa Paulus memiliki penyakit ayan. Namun hebatnya jemaat Galatia tidak memandang hina dan jijik Paulus. Jijik dalam bahasa Yunani secara harafiah artinya meludahi, jadi jemaat Galatia tidak meludahi Paulus oleh karena penyakitnya, bahkan menerima dia seperti menyambut Kristus.

Dan Paulus melanjutkan di Galatia 4:15 dia mengatakan bahwa "jika mungkin kamu mencungkil matamu dan memberikannya kepadaku”. Dari perkataan Paulus ini mengindikasikan bahwa ada sesuatu yang salah dengan matanya. Hal ini juga mungkin saja benar terjadi, ditambah kenyataan bahwa tidak semua surat Paulus ditulisnya sendiri, biasanya ada surat yang ia diktekan dan pada akhirnya dia menulis beberapa kalimat yang isinya salam pribadi dan ia menyertakan tanda tangannya dalam surat tersebut sebagai tanda bahwa benar surat tersebut ia yang menulisnya.

Pernyataan ini didukung dengan perkataan Paulus dalam Galatia 6:11 "Lihatlah betapa besarnya huruf-huruf yang kutulis kepadamu dengan tanganku sendiri”. Seakan-akan Paulus sedang menundukkan kepalanya dekat-dekat pada sehelai kertas demi menuliskan suratnya dan ia menyadari bahwa tulisannya sendiri terlalu besar sebab penglihatannya sudah kabur. ${ }^{15}$

\footnotetext{
${ }^{15}$ William Barclay, Duta Bagi Kristus: Latar Belakang Peta Perjalanan Paulus, (Jakarta: BPK Gunung Mulia), 1985, hal. 5
} 
Rowan William dalam bukunya Jumpa Allah Dalam Paulus, berpendapat bahwa ada kemungkinan ia menderita salah satu dari sekian banyak penyakit selama perjalanannya, yang menjelaskan kembali bahwa dalam hal penampilan ia tidak menarik, dengan mata bengkak yang bahkan mungkin kelopak matanya bernanah. ${ }^{16}$

Betapa menderitanya Paulus ketika ia harus mengalami suatu "duri" atau "pasak" yang ada dalam dagingnya. Bahkan untuk aktivitas biasa saja orang dengan penglihatan yang kabur susah untuk keluar bahkan melakukan aktivitas sehari-hari, namun tidak dengan Paulus, justru dalam setiap keterbatasan dan kelemahannya, ia tetap bergairah dan bersemangat untuk membawa kabar baik itu di berbagai wilayah. Itu merupakan buah dari pengenalanya yang benar akan Kristus sehingga ia tetap kuat dan semangat meskipun banyak hal yang harus ia alami selama perjalanan misinya.

Kedua, merupakan sakit kepala yang hebat, ada yang menafsirkan bahwa Paulus memiliki sakit kepala yang hebat, hal ini dimungkinkan karena penglihatannya yang kabur sehingga berdampak pada sakit kepala yang hebat. Namun ada pula yang berpendapat bahwa Paulus mengalami penyakit demam malaria yang parah, yang memang sudah lazim terjadi di Pantai Asia Kecil.

Mungkin demam malaria ini terjadi saat Paulus dalam perjalanan dan orang-orang yang pernah mengalami demam malaria yang sama yang juga didapatkan di sekitar Pantai Asia Kecil mengatakan bahwa rasa sakit yang ditimbulkan dari demam malaria itu bagaikan ada besi yang panas menusuk kedalam dahi, atau seoalah-olah ada bor yang menembus kepala. ${ }^{17}$

Ketiga, merupakan utusan Iblis, ada pula yang menafsirkan bahwa "duri” dalam daging yang dimaksud Paulus adalah masalah-masalah yang dilakukan oleh utusan Iblis yang telah

\footnotetext{
16 Rowan William, Jumpa Allah Dalam Paulus, (Jakarta: Waskita Publishing), 2014, hal. 32.

${ }^{17}$ William Barclay, Duta Bagi Kristus: Latar Belakang Peta Perjalanan Paulus, (Jakarta: BPK Gunung Mulia), 1985, hal. 5.
} 
memukulnya. Tetapi di ayat yang ke 7 itu Paulus tidak menyatakan dengan spesifik dengan apa sebenarnya utusan iblis itu memukulnya. Kemungkinan utusan iblis itu berkali-kali mencegah atau menghalangi perjalanan Paulus seperti ada tertulis dalam I Tesalonika 2:18. ${ }^{18}$

Dalam ayat-ayat sebelumnya (ayat 1-5) Paulus mengatakan bahwa ia mendapat penglihatan dan penyataan dari Allah mengenai seorang Kristen, empat belas tahun yang lampau, yang mengalami suatu penyakit entah didalam tubuh, atau di luar tubuh, tetapi ia diangkat ketingkat yang ke tiga dari sorga di Firdaus.

Kata "tingkat ketiga dari sorga" merupakan cara orang Yunani mengungkapkan kehadiran Allah secara langsung, ${ }^{19}$ yang merupakan tempat kediaman Allah dan tempat tinggal bagi setiap orang percaya yang telah meninggal. Tentunya ini merupakan pengalaman luar biasa dan istimewa bagi manusia biasa seperti Paulus. Namun Paulus mengatakan seolah-olah itu adalah pengalaman orang lain yang dia tahu atau dengar, padahal sebenarnya orang itu adalah dirinya sendiri, dikatakan sebenarnya ia merasa malu untuk menceritakan pengalaman terindahnya selama menjadi pengikut Kristus, dan ia tidak ingin menceritakan hal tersebut sebab ia tidak ingin dianggap sombong. ${ }^{20}$

Di sisi lain ada rasul-rasul palsu yang memegahkan diri atas penglihatan mereka dan menyatakan bahwa Paulus hanya berani apabila dia jauh, ${ }^{21}$ sehingga mau tidak mau Paulus terpaksa mengatakan pengalamannya tersebut, meskipun seolah-olah itu di alami oleh orang lain. Paulus mengatakan hal tersebut bukan untuk memegahkan dirinya atas penglihatan dan penyataan yang ia terima, namun kembali untuk menjelaskan sebuah "duri” dalam daging yang menjadi kelemahannya tersebut, Paulus ingin menegaskan betapa besar kasih Allah atas dirinya

\footnotetext{
${ }^{18}$ Ibid. hal. 5

19 _ Tafsiran Alkitab Masa Kini 3 Matius-Wahyu, (Jakarta: Yayasan Komunikasi Bina Kasih,) 1992, hal. 532 .

${ }^{20} \mathrm{~J}$ Wesley Brill, Tafsiran Surat Korintus Kedua, (Bandung: Kalam Hidup), 1996, hal. 172.

${ }^{21}$ St. Darmawijaya Pr, Sekilas Bersama Paulus, (Yogyakarta: Kanisisus), 1992, hal. 112.
} 
yang begitu lemah sehingga memberikan kepadanya suatu penglihatan, terlebih lagi mempertegas mengenai kerasulannya, yang mulai diragukan.

Memang benar dalam segi fisik atau penampilan Paulus tidaklah lebih hebat dari para rasul-rasul palsu itu, dimana Paulus adalah seorang yang kecil perawakkannya, botak, kaki bengkok, memiliki badan yang tegap, alis yang tersambung dang hidung yang bengkok. Hal-hal itulah yang membuat rasul-rasul palsu memprovokasi jemaat di Korintus untuk meragukan kerasulan Paulus bahkan meremehkan Paulus hanya karena bentuk fisiknya. Kendati demikian, Paulus adalah seorang yang penuh belas kasihan, sebab terkadang ia kelihatan seperti manusia dan kadang-kadang wajahnya nampak seperti malaikat. ${ }^{22}$

Kemudian diayat yang ke 9 inilah, Tuhan menjawab doa Paulus, yang dalam King James Version (KJV), yaitu: "And he said unto me, My grace is sufficient for thee: for my strength is made perfect in weakness."23

Terjemahan Bahasa Indonesia Masa Kini (BIMK), “Tetapi Tuhan menjawab: “Aku mengasihi engkau dan itu sudah cukup untukmu; sebab kuasa-Ku justru paling kuat kalau kau dalam keadaan lemah."24

Yang menarik jawaban Tuhan diawali dengan sebuah kata tetapi, yang artinya kontras atau berlawanan dengan harapan Paulus. Kata "tetapi” disini dalam bahasa Yunani berasal dari kata $\kappa \alpha l(k a i)$, merupakan kata konjungsi atau kata hubung, yang dalam bahasa inggris artinya and, also, both, but, even, for, if, so,that, then, therefore, when, yet, yang artinya dan, juga, bahkan, dan khususnya, memang, bahwa, yaitu, ketika, maka, adapun, demikian, demikian juga,

\footnotetext{
22 1996, hal. 208.

${ }^{23}$ Aplikasi Android KJV, Versi 4.5.5, SABDA dan Tim Alkitab Android 2019.

${ }^{24}$ Aplikasi Android BIMK, Versi 4.5.5, SABDA dan Tim Alkitab Android 2019.
} 
sehingga, malah, namun, walaupun, padahal, kemudian, lalu, karena, bukan saja...tetapi juga, atau dari. $^{25}$

Secara kontekstual arti kata yang pas untuk hal ini adalah tetapi atau namun. Seperti yang diterjemahkan oleh Lembaga Alkitab Indonesia yang menggunakan kata tetapi. Hal ini dikarenakan jawaban Tuhan tidak seperti apa yang diharapkan Paulus, yakni supaya ia terlepas dari "duri" dalam daging seperti yang dijelaskan diayat-ayat sebelumnya. Bentuk waktu dalam kalimat "tetapi jawab Tuhan kepadaku" adalah perfek, yang artinya Paulus meskipun ia sungguh-sungguh berharap bahwa duri itu lepas dari padanya, Paulus juga benar-benar pasrah terhadap apapun jawaban Tuhan.

Kemudian kata pertama setelah jawaban Tuhan adalah Cukuplah yang berasal dari

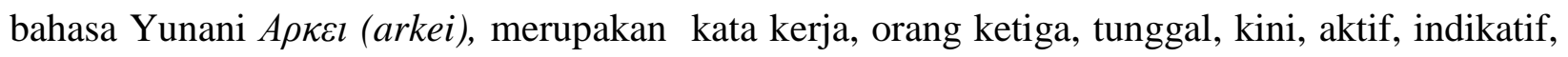
dari kata dasar $\alpha \rho \kappa \varepsilon o$ (arkeo) yang dalam bahasa Inggris berarti content, enough, satisfied, sufficient. Dalam bahasa Indonesia artinya puas hati, cukup, mencukupi, telah memuaskan. ${ }^{26}$

Ini merupakan kata pertama dari jawaban Tuhan “cukuplah" artinya dapat memenuhi kebutuhan, atau memuaskan keinginan. ${ }^{27}$ Dari ayat ini jelas bahwa Tuhan menolak harapan Paulus untuk melepaskan "duri" yang ada dalam dagingnya, sebab Tuhan sendiri akan memenuhi kebutuhan atau memuaskan keinginan Paulus, sama juga artinya dengan Tuhan akan menyertai Paulus dalam segala keadaannya .

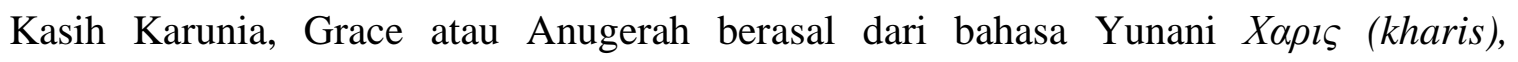
merupakan kata benda dengan gender feminine, tunggal, nominatif, memiliki beberapa kegunaan yang obyektif, yang mana artinya menganugerahkan atau kesempatan yang menyenangkan,

\footnotetext{
${ }^{25}$ Hasan Sutanto, Perjanjian Baru Interlinear-Konkordansi Jilid II, (Jakarta: Lembaga Alkitab Indonesia), 2014, hal. 88.

${ }^{26}$ Ibid. hal. 106

${ }^{27}$ Departemen Pendidikan Dan Kebudayaan, Kamus Besar Bahasa Indonesia, (Jakarta: Balai Pustaka), 1988, hal. 175.
} 
anugerah-pemberian, kemurahan hati, senang, keramahan, syukur, pahala atau faedah, hal yang patut dipuji seperti yang tertulis dalam Lukas 2:40, 2 Kor 8:6, Lukas 4:22, I Korintus 1:4. ${ }^{28}$

Dalam King James Version (KJV) disebut grace atau anugerah, dalam kitab Perjanjian Baru kata ini telah disebutkan sebanyak 155 kali. Menurut Kamus Besar Bahasa Indonesia anugerah adalah pemberian atau ganjaran dari pihak atas (orang besar dan sebagainya) kepada pihak bawah (orang rendah dan sebagainya), karunia dari Tuhan sedangkan menganugerahkan yaitu memberi sesuatu sebagai anugerah. ${ }^{29}$ Jadi, anugerah (kharis) yang dimaksud dalam ayat ini adalah sesuatu yang diberikan atasan kepada bawahan, yaitu sesuatu yang diberikan Kristus sebagai atasan kepada Paulus sebagai bawahan atau hamba secara gratis atau cuma-cuma.

Anugerah yang dimaksud disini secara kontekstual dari ayat-ayat sebelumnya yakni ayat 1-6, dimana Paulus menceritakan bahwa dirinya mengalami penglihatan dan penyataan dari Allah mengenai surga dan Firdaus yang merupakan anugerah terindah Paulus dalam pengalamannya mengikut Kristus. Namun secara umum juga dimungkinkan jika anugerah yang dimaksud adalah semua anugerah Tuhan yang diberikan kepada Paulus termasuk pengenalannya akan Kristus.

Di ayat ini ada kata hubung yaitu $\Gamma \alpha \rho($ gar $)$ yang merupakan konjungsi, artinya sebab, ${ }^{30}$ dalam Kamus Besar Bahasa Indonesia (KBBI) sebab adalah hal yang menjadikan timbulnya sesuatu, lantaran, karena, asal mula, dan hal ini berkaitan dengan kata sebelum dan kata berikutnya yang saling berhubungan sebab akibat. Konjungsi ini menjelaskan sebab akibat dari

\footnotetext{
${ }^{28}$ Hasan Sutanto, Perjanjian Baru Interlinear-Konkordansi Jilid II, (Jakarta: Lembaga Alkitab Indonesia), 2014, hal. 759.

${ }^{29}$ Departemen Pendidikan Dan Kebudayaan, Kamus Besar Bahasa Indonesia, (Jakarta: Balai Pustaka), 1988, hal. 44 .

${ }^{30}$ Hasan Sutanto, Perjanjian Baru Interlinear-Konkordansi Jilid I, (Jakarta: Lembaga Alkitab Indonesia), 2014, hal. 115
} 
kata sebelum ke kata sesudahnya, yakni alasan Tuhan mengapa Ia tidak mengabulkan doa Paulus, sebab telah cukup kasih Karunia Tuhan kepada Paulus.

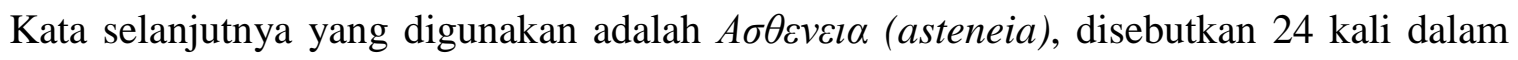
Perjanjian Baru merupakan kata benda, feminine, tunggal, datif (obyek tak langsung/kepada), yang memiliki terjemahan kelemahan, ketidakberdayaan (tidak selalu dalam pengertian negatif), penyakit, keadaan kurang percaya diri, kegentaran. ${ }^{31}$ Dalam bahasa Inggris kelemahan adalah diseases, ill, illness, infirmities, sickness, sicknesses, weak, weakness, weaknesses. Dalam bahasa Indonesia artinya sakit, penyakit, lemah, kelemahan.

Kelemahan di ayat 9 ini mengacu pada konteks sebelumnya yang Paulus sebut sebagai "duri" dalam daging. Secara gramatikal berarti "duri" dalam daging itu adalah suatu sakit penyakit yang rupanya menjadi kelemahan bagi Paulus, meskipun banyak pula tafsiran yang menyebutkan hal lain seperti telah dijelaskan sebelumnya.

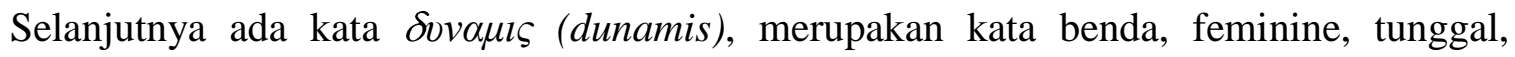
nominatif, yang berarti kuasa-Ku, dalam bahasa Inggris ability, meaning, mightily, mighty, miracle, miraculous powers, power, powers, strength, wealth. Atau menurut Perjanjian Baru Interlinier-Konkordansi (PBIK) Jilid I artinya kesanggupan, kuasa, kekuatan, arti, berkuasa, mukjizat, kekuatan ekonomi, kekayaan, yang banyak, tentara, kuasa supernatural, pemberi kuasa, Yang Mahakuasa. ${ }^{32}$

Yang dimaksud kuasa-Ku disini adalah Tuhan memiliki kesanggupan, kekuasaan dan kekuatan untuk memenuhi segala kebutuhan Paulus, memuaskan keinginan Paulus meskipun ia dalam keadaan sakit atau bahaya, Tuhan memiliki kesanggupan untuk menyertai Paulus dalam sakit penyakitnya dan kelemahannya.

\footnotetext{
${ }^{31}$ Ibid. hal. 115.

${ }^{32}$ Hasan Sutanto, Perjanjian Baru Interlinear-Konkordansi Jilid II, (Jakarta: Lembaga Alkitab Indonesia), 2014, hal. 213 .
} 


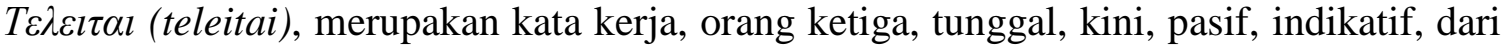
kata dasar teleo yang berarti mengakhiri, menyelesaikan, melakukan, menaati, terjadi, mewujudkan, membayar, ${ }^{33}$ dan etai merupakan orang ketiga tunggal pasif, jadi terjemahannya adalah dia yang diakhiri, dia yang diselesaikan, dia yang dilakukan, dia yang ditaati, dia yang dijadikan dan dia yang dia yang diwujudkan, serta dalam bahasa Inggris memiliki arti accomplished, carried, carry, completed, finish, finished, fulfilled, fulfilling, keeps, pay, perfected, performed. Dalam bahasa Indonesia artinya menyempurnakan, menyelesaikan, melaksanakan, memenuhi, membawa, menjaga, membayar.

Hal ini berarti sesuatu yang kurang, akan dipenuhi, dilengkapi, dan disempurnakan sehingga tidak lagi kekurangan. Dalam ayat ini yang dimaksud adalah justru sesuatu yang kurang akan dipenuhi, yang tidak sempurna akan disempurnakan, yang belum selesai akan di selesaikan. Sama halnya dengan Paulus, jika ia tidak memiliki kekurangan maka tidak akan ada kepenuhan, jika tidak ada ketidaksempurnaan maka tidak akan disempurnakan. Justru sesuatu yang kuranglah yang akan dipenuhi atau di puaskan, yang tidak sempurnalah yang akan disempurnakan. Demikian Paulus, justru dengan adanya "duri" dalam daging itu Tuhan akan memenuhkan, memuaskan dan menyempurnakannya.

Mendengar jawaban Tuhan, Paulus tidak berkecil hati karena doa dan harapannya tidak dikabulkan Tuhan. Sebagai tanggapan atas jawaban Tuhan justru, Paulus merasa bangga dan senang, senang dalam ayat ini menggunakan bahasa Yunani $\varepsilon \delta \imath \sigma \tau \alpha$ (edista), kata sifat, superlatif, yang artinya dengan amat senang hati, superlatif menandakan bahwa kata ini memiliki arti

33 Ibid, hal. 703. 
mendalam atau amat sangat jadi Paulus sedang merasakan senang hati yang amat sangat, tentunya hal ini karena jawaban Tuhan atas kelemahannya. ${ }^{34}$

M $\alpha \lambda \lambda o v$ (mallon), kata keterangan, komparatif, berarti lebih baik, dalam bahasa Inggris all the more, better, especially, much, rather, still more, truer. Dalam Bahasa Indonesia artinya lebih dari semua, lebih baik, terutama, banyak, lebih lagi. Sedangkan dalam Perjanjian Baru interlinier-Konkordansi (PBIK) Jilid II dapat diartikan dengan lebih, melainkan, malah. ${ }^{35}$ Setelah merespon jawaban Tuhan senang hati Paulus malah, atau justru akan melakukan tindakan yang lebih baik daripada mengeluh dan memohon kepada Tuhan agar Dia melepaskan Paulus dari “duri” dalam daging tersebut, sebab Paulus sadar akan Kasih dan Kuasa Tuhan yang nyata sempurna dalam kelemahannya.

Paulus tidak lagi mengeluh atau meminta dilepaskan dari penyakitnya justru ia akan

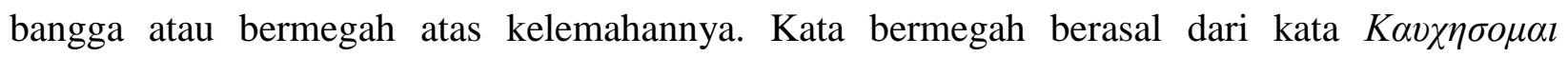

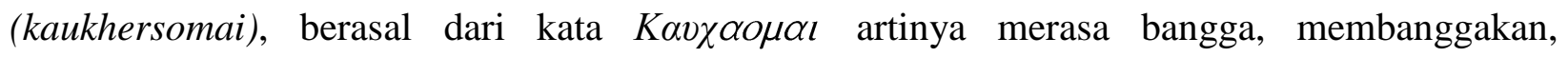
menyombongkan, yang merupakan kata kerja, orang pertama, tunggal, futur (yang akan terjadi), medial refleksif (tindakan yang dikerjakan memantul pada dirinya sendiri), indikatif, artinya aku akan merasa bangga sendiri. ${ }^{36}$

Dalam bahasa Inggrisnya, boast, boasted, boasting, boasts, exult, glory, take pride. Arti dalam bahasa Indonesia adalah membanggakan, bangga, bersukaria, memasyurkan, berbangga. Dalam Perjanjian Baru kata ini muncul sebanyak 37 kali seperti kata "bermegah" dalam II Korintus 12:5-6, Paulus akan merasa bangga kepada dirinya sendiri jika ia merasakan anugerah dari Tuhan dalam kelemahannya.

\footnotetext{
${ }^{34}$ Hasan Sutanto, Perjanjian Baru Interlinear-Konkordansi Jilid II, (Jakarta: Lembaga Alkitab Indonesia), 2014, hal. 809.

${ }^{35}$ Ibid, hal.469.

${ }^{36}$ Hasan Sutanto, Perjanjian Baru Interlinear-Konkordansi Jilid II, (Jakarta: Lembaga Alkitab Indonesia), 2014, hal. 415.
} 
Dan inilah tujuan akhir Paulus setelah ia meminta penyakitnya disembuhkan Tuhan, lalu Tuhan menjawab doanya, kemudian ia tersadar dan ia menjadi bangga dalam kelemahannya, kata ini merupakan tujuan final atau akhir Paulus, kata ini berasal dari bahasa Yunani $\imath v \alpha($ hina), muncul sebanyak 663 kali dalam Perjanjian Baru, kata ini merupakan konjungsi, dengan tujuan final atau tujuan akhir yang berarti supaya, sehingga, untuk, bahwa, karena ini, yaitu, kiranya. ${ }^{37}$ Tujuan akhir Paulus bermegah dalam kelemahannya adalah supaya Kuasa Tuhan akan dinyatakan atau turun atasnya.

Hal ini menunjukkan bahwa Paulus sungguh mengerti dan memahami apa tujuan Tuhan mengijinkan "duri” dalam daging itu ada dalam diri Paulus. Justru karena itulah Tuhan akan menyatakan kuasa-Nya dengan sempurna. Mendengar jawaban Tuhan yang demikian membuat Paulus menjadi berbangga telah memiliki kelemahan yaitu sakit penyakitnya ataupun bahkan keadaannya dalam menyebarkan Injil. Tujuan Paulus berbangga bukan untuk menyombongkan diri atas Karunia penglihatan yang Tuhan berikan seperti tercatat dalam ayat-ayat sebelumnya, namun justru ia berbangga atas kelemahannya sebab ia tahu lewat kelemahannya itulah Tuhan memperhatikan hidupnya, menyertai dia, dan bahkan menurunkan Kuasa-Nya untuk menyempurnakan kekurangan Paulus.

Ayat selanjutnya (ayat 10) Paulus menyatakan bahwa ia akan senang dan rela dalam kelemahannya, yaitu dalam siksaan, kesukaran, penganiayaan, dan kesesakan karena Kristus.

Kata terakhir dalam perikop ini merupakan kata penutup yang singkat, tegas, lugas dan jelas dari Paulus sebagai penutup, Paulus berkata:"Sebab jika aku lemah, maka aku kuat."

\footnotetext{
${ }^{37}$ Ibid, hal. 372.
} 


\section{PENUTUP}

\section{Kesimpulan}

Dari penggalian ayat secara eksegesa diatas, penulis dapat mengambil kesimpulan bahwa, ayat sembilan merupakan jawaban Tuhan atas doa atau permohonan Paulus yang sebelumnya Paulus mengeluh kepada Tuhan atas suatu "duri" didalam dagingnya, yang ia sebut datang dari utusan iblis. Paulus secara sungguh-sungguh bahkan berulang kali (tiga kali) memohon kepada Tuhan untuk melepaskan dirinya dari "duri” dalam daging tersebut.

Tuhan menjawab doa Paulus dengan mengatakan bahwa Kasih Karunia-Nya telah cukup kepada Paulus, yakni segala hal tentang pengenalannya kepada Kristus, penglihatannya dan penyataan yang Tuhan berikan kepada Paulus tentang surga atau Firdaus. Mengenai "duri" dalam daging yang diderita Paulus yang membuat itu sebagai kelemahan Paulus, Tuhan berkata justru dalam kelemahanlah atau melalui "duri" itulah Tuhan mau mengaruniakan Kuasa-Nya secara sempurna kepada Paulus. Sebab Tuhan tidak bekerja dalam kekuatan manusia atau kesempurnaan, justru Tuhan memakai kelemahan Paulus yakni "duri” dalam dagingnya itu (penyakit, kesukaran, kesesakan) untuk menyalurkan Kuasa-Nya yang begitu nyata dan sempurna.

Mendengar jawaban Tuhan itu, Paulus beralih yang awalnya berfokus pada kelemahannya sehingga ia meminta kepada Tuhan untuk melepaskan dari kelemahannya tersebut, ia kini berfokus pada kuasa yang Tuhan nyatakan secara sempurna justru dalam kelemahannya. Paulus justru bangga akan kelemahnnya, semakin besar kelemahan yang dia alami maka Tuhan akan semakin menyatakan kuasa-Nya. Maka terlebih suka dan bangga Paulus menjadi manusia yang menderita karena Kristus karena hal itu akan mendatangakan naungan Kuasa dan Kasih Tuhan dalam hidupnya. 
Paulus bukanlah seorang yang kuat sehingga ia dapat berjalan $9000 \mathrm{~km}$ untuk menyebarkan Injil. ${ }^{38}$ Dalam benak orang percaya mungkin Paulus seorang yang begitu kuat, hebat, tangguh, pintar, mungkin pula ada yang beranggapan fisiknya kuat, tegap, tinggi. Namun ternyata tidak, Paulus adalah orang yang lemah, dalam sakitnya, lelahnya bahkan fisiknya yang kecil dan pendek. Tetapi Tuhan tidak memandang semua itu, Ia mau menyatakan Kasih dan Kuasa-Nya yang begitu dahsyat dan sempurna justru kepada seorang yang lemah, sakit dan fisik yang tidak sempurna yang bernama Paulus.

Paulus ada karena Kuasa Tuhan yang datang menaungi dia, dan Injil bisa tersebar ke seluruh penujuru dunia, salah satunya karena Paulus, seorang yang lemah itu, yang dipakai Tuhan secara luar biasa. Andaikan Paulus tidak menyadari bahwa melalui kelemahannya Kuasa Tuhan dinyatakan, jika Paulus hanya berfokus pada kelemahannya sehingga hal itu menghambat pelayanan penginjilannya, maka mungkin saja hari ini semua orang diluar Yahudi belum mendengar kabar keselamatan, dan keselamatan hanya akan didengar oleh bangsa Israel saja.

\section{Aplikasi}

Tidak ada manusia yang sempurna dibawah kolong langit ini. Semua manusia memiliki kelemahan, baik dalam keadaan fisik, mental maupun keadaan. Banyak orang merasa rendah diri oleh karena suatu kelemahan, suatu keadaan, atau suatu penyakit, sehingga orang tersebut menyerah untuk segala hal dalam hidupnya karena berfokus pada kelemahan tersebut dan tidak dapat memaksimalkan bahkan ada yang tidak dapat menemukan potensinya karena hal itu.

Namun belajar dari II Korintus 12:9 ini, Tuhan berkata bahwa justru dalam kelemahan manusialah Dia akan berkarya, menyatakan Kuasa-Nya yang sempurna. Jangan hanya berfokus

\footnotetext{
${ }^{38}$ William Barclay, Duta Bagi Kristus: Latar Belakang Peta Perjalanan Paulus, (Jakarta: BPK Gunung Mulia), 1980, hal. 3.
} 
pada kelemahan kita, sebab jika demikian kita tidak akan tahu rencana Tuhan dan hal itu akan menghambat karya Tuhan dalam kehidupan kita. Berfokuslah kepada Tuhan, apa yang Tuhan mau sehingga Ia mengijinkan kelemahan itu ada dalam diri manusia.

Mari belajar pula untuk mengerti kehendak Tuhan, mungkin saja Tuhan mengijinkan suatu duri dalam daging sebagai alat kendali, rem atau pengingat (reminder) agar manusia tidak menjadi sombong dan ingat bahwa semua yang didapatkan semata-mata hanya anugerah dan kasih Tuhan. Dalam kehidupan di dunia ini besar sekali peluang manusia untuk menjadi sombong, bahkan dalam dunia pelayanan sekalipun. Setelah mengerti hal ini, kita belajar bahwa Tuhan mengijinkan semua hal yang mungkin bagi kita menjadi duri dalam daging namun hal itu pada akhirnya mendatangkan kebaikan.

Belajarlah juga dari pribadi Paulus yang mau bertanya, mengerti dan melakukan apa yang Tuhan mau. Meskipun ia dalam keadaan lemah fisik dan dalam keadaan yang sangat menderita selama perjalanannya, namun ia sadar bahwa melalui itu semua Tuhan mau memakai dirinya sebagai alat-Nya. Sehingga Paulus mengambil keputusan untuk tetap terlibat dalam penyebaran Injil walaupun dalam keadaan lemah, bahkan sakit. Oleh sebab itu Paulus bangga dan bermegah justru dalam kelamahan dan ia berkata meskipun dalam kelemahannya Tuhan mau menopang dan menjadi kekuatannya, Paulus menyimpulkan dalam ayat 10 yang berkata ketika ia lemah, maka ia kuat. 


\section{DAFTAR PUSTAKA}

, Alkitab Penuntun Hidup Berkelimpahan, Malang: Gandum Mas, 1994.

, Ensiklopedi Alkitab Masa Kini Jilid II M-Z, Jakarta: Yayasan Komunikasi Bina Kasih, 1996.

, Tafsiran Alkitab Masa Kini 3 Matius-Wahyu, Jakarta: Yayasan Komunikasi Bina Kasih, 1992

, Tafsiran Alkitab Wycliffe, Malang: Gandum Mas, 2013.

Barclay, William, Duta Bagi Kristus: Latar Belakang Peta Perjalanan Paulus, Jakarta: BPK Gunung Mulia, 1985.

Brill, J Wesley, Tafsiran Surat Korintus Kedua, Bandung: Kalam Hidup, 1996.

Departemen Pendidikan Dan Kebudayaan, Kamus Besar Bahasa Indonesia, Jakarta: Balai Pustaka, 1988.

Hulu, Yupiter, Diktat Pengantar Perjanjian Baru, Yogyakarta: Sekolah Tinggi Theologia Nazarene Indonesia, 2013.

Owen, W. Stuart, Grist P.A, dkk, Bahasa Lambang Alkitab, Jakarta: Yayasan Komunikasi Bina Kasih, 2003.

Pr. St. Darmawijaya, Sekilas Bersama Paulus, Yogyakarta: Kanisisus, 1992.

Sutanto, Hasan, Perjanjian Baru Interlinear Yunani-Indonesia dan Konkordansi Perjanjian

Baru (PBIK) Jilid I, Jakarta: Lembaga Alkitab Indonesia, 2014.

Sutanto, Hasan, Perjanjian Baru Interlinear Yunani-Indonesia dan Konkordansi Perjanjian

Baru (PBIK) Jilid II, Jakarta: Lembaga Alkitab Indonesia, 2014.

William, Rowan, Jumpa Allah Dalam Paulus, Jakarta: Waskita Publishings, 2014. 
Aplikasi Alkitab Android

Aplikasi Android TB, Versi 4.5.5, SABDA dan Tim Alkitab Android 2019.

Aplikasi Android KJV, Versi 4.5.5, SABDA dan Tim Alkitab Android 2019.

Aplikasi Android BIMK, Versi 4.5.5, SABDA dan Tim Alkitab Android 2019.

Aplikasi Android NIT, Versi 4.5.5, SABDA dan Tim Alkitab Android 2019.

Aplikasi VMD, Versi 4.5.5, SABDA dan Tim Alkitab Android 2019. 